\title{
Cultural colonialism as a result of commercial activities: the linguistic perspective
}

\author{
ALESSIA BAUER
}

Bauer, A. 2019. Cultural colonialism as a result of commercial activities: the linguistic perspective. AmS-Skrifter 27, 163-174, Stavanger, ISSN 0800-0816, ISBN 978-82-7760-183-0.

The Hanse played not only a prominent economical role in the North Atlantic but the Germans also consistently influenced the culture of the people with whom they interacted and traded. Their presence led to a sort of cultural colonialism in Northern Europe, which, among others things, substantially shaped the Scandinavian languages. For several reasons, the Icelandic language was not influenced in the same way as the other Scandinavian languages; yet, one can find some traces of German in administrative language dating back to the Middle Ages. Furthermore, 'cultural colonization' by the Germans also certainly took place through the Reformation in Iceland. It was the German merchants who took the first seeds of the new faith with them to Iceland and marked their 'conquest' by building a Lutheran church. In this way, the merchants - like colonialists - claimed a space on foreign ground for themselves, where language played a very central role.

Alessia Bauer, Institut für Nordische Philologie, Ludwig-Maximiliams-Universität München, Amalienstr. 83, D-80799 MÜNCHEN, GERMANY. E-mail: alessia.bauer@lrz.uni-muenchen.de

Keywords: cultural colonialism, inter-Scandinavian communication, language contacts, loanwords, Reformation, semi-communication, strategies of communication

In the following, I will try to sketch the concept of 'cultural colonialism' and apply it to the activities of the Germans within the North Atlantic area, focusing on the linguistic aspects and differentiating between continental-Scandinavian and Icelandic. I am convinced that language can be used as a tool of 'conquest' quite separate from that of a military campaign, but which does not necessarily have to be less effective. In doing so, I am very aware of the fact that historians have another understanding of 'colonialism' and for this reason I prefer to take a sociological approach to the topic.

Linguistic contacts are quite complex phenomena and this is not only due to purely linguistic factors as for example the similarity among languages. Just to give an example, let us consider Estonian, Eesti, a Finno-Ugric language with nothing in common with the Germanic language family. Despite the differences, it happens that this language shows an impressive number of Germanisms from Middle Low German. These occurrences are due to socio-political factors, such as the strong German presence in the region, as well as to the fact that the first extant Estonian book is a bilingual German-Estonian translation of the Lutheran catechism by S. Wandradt and J. Koell, dating to 1535 and published in Wittenberg. ${ }^{1}$ Indeed, the institute for Estonian language in Tallinn reports that about $25 \%$ of Estonian vocabulary has been influenced by the German language. This gradual influence allegedly occurred in four distinct periods in Estonian history, stretching for about 700 years from the Middle Ages until the Early Modern period. ${ }^{2}$

Thus, at the beginning of this contribution, it is necessary for me to outline the nature of linguistic contacts first, i.e. some direct and some mediate ones. Afterwards I will explain what I mean by 'cultural and linguistic colonialism' and thereby argue, by means of a few examples, the influence of (Middle) Low German on the Scandinavian languages and Icelandic language. Additionally, I will explain, in my opinion, 
why this kind of influence can be understood as 'cultural colonialism'.

\section{General considerations about the nature of language contacts}

Language should not be studied as an abstract topic as it is always the product of social relationships, but rather it should be integrated in a social context. Since extra-linguistic, social, economic and ideological factors play, generally speaking, a very relevant role in the topic I am going to consider, a socio-linguistic approach should be preferred. As a matter of fact, language is deeply connected to speakers and their reality and, in my opinion, it cannot be separated and abstracted from a concrete context of communication.

As relationships between people and nations are manifold, contact between languages also takes place in different ways: it can be the result of the direct interaction of people speaking different languages as their mother tongue, or it can occur through mediate contact without physical movement of people, for example through books and other media. When people who speak different languages come into contact with each other, different strategies of communication can be developed: firstly, the stronger group can impose its own language, and depending on the way this occurs, we can speak of 'cultural colonialism' or even 'cultural imperialism. ${ }^{3}$ Secondly, both groups can use a so-called lingua franca, such as Latin in medieval Europe. Thirdly, they can create a sort of 'comprise language', like pidgin or creole during the colonial period in America. Finally, in case of two genetic closely related languages, it is possible that each group speak its own language and have a passive understanding of the other language, as is still the case today in continental Scandinavia, a phenomenon called inter-Scandinavian communication. In this case, it is appropriate to speak of a situation of 'semi-communication' as Kurt Braunmüller termed it. ${ }^{4}$ According to his definition, semi-communication is the 'understanding by means of using the mother tongue during contact with genetically close related languages'. ${ }^{5}$

Yet, the reasons for adopting the one or the other strategy of communication is not only due to linguistic factors, but the socio-cultural perspective plays the most important part in the choice of the strategy. ${ }^{6}$ These factors vary due to several circumstances (for instance trade, official institutions or religion) and due to their occurrence in social settings, which can also differ within the same society. ${ }^{7}$ Some considerations can help to exemplify this in relation to Scandinavia: continental Europe, in particular the Holy Roman Empire, was considered more progressive and advanced from a cultural point of view. Therefore, in the contact between Low German and the Scandinavian idioms, the former was regarded as a 'culture carrier' that gave prestige to the Scandinavian upper class if they would adopt it as their own language. ${ }^{8}$ Looking at the vocabulary of Old Norwegian, Edith Marold affirmed that the lower class in Norway certainly did not understand Low German, hence in order to get their orders filled, the Germans adopted Old Norse words (such a word is elda meaning 'light a fire').9 Thus, this simple example shows that the nature of linguistic contact is and must be flexible.

\section{Different kinds of language contacts}

It is stated at the very beginning of an anthology edited by Kurt Branmüller and Juliane House that all languages have been more or less strongly influenced by contact with other languages, which means, as a consequence, that all languages represent a mixture of linguistic contacts. 'No existing language can be said to be a pure monolithic and homogeneous entity', ${ }^{10}$ and this is true even between different language families, as stated above in relation to Estonian and German. Icelanders would like to think of their language as such a 'monolithic entity'; however, there was a period in Icelandic history when the above-mentioned statement was also true for the Icelandic language, surely even more so than at the beginning of the twentieth century.

The contact between Germans and Scandinavians (including Icelanders) took place in different periods in history and was induced by several factors. From the ninth century onwards, the missionary work of German monks, such as Ansgar from Bremen (801-65), known as the 'apostle of the North', led to the first direct contact between Germans and Scandinavians. The missionary activities continued in the following centuries; in the tenth century, the Danish King Harald Gormsson Bluetooth was supposedly baptized in Germany around the year 960.

Even if mediation began with some delay, the Icelandic language also records a good number of loanwords, for the most part in the ecclesiastical and learned spheres, but secular words too, probably introduced by clerics. ${ }^{11}$ Moreover, Christian Westergård-Nielsen identified an effective instrument for introducing borrowings in commercial activities. In the High Middle Ages, the trade activities of the Hanse led to the direct contact of people travelling from country to country who had to 
communicate with one another. The interaction with foreign merchants led to the adoption of new words, at least in the spoken language, and from thereon in popular literature as well, such as rimur or specialist literature, which were like handbooks for semi-literate people. $^{12}$

Eventually, in the sixteenth century, the Reformation gave the opportunity to more direct language interaction through the clergy, as they were partly educated in Wittenberg and at other German universities (such as Rostock). Additionally, mediate language contact also occurred through the numerous German books on catechism that reached Scandinavia and Iceland. ${ }^{13}$

The area of present-day Germany was a meeting point for Icelanders who came to Europe in order to attain a higher degree of education; among them, we find clerics such as Gizur Einarsson (bishop of Skálholt 1540-48) and Guðbrandur Porláksson (bishop of Hólar from 1571-1627) as well as the scholar and humanist, Arngrímur lærði Jónsson (1568-1648). Through these contacts, the Lutheran chants of Philipp Otto Nicolai (1556-1608) were adopted into the Icelandic liturgy where they are still used in the hymn books of Iceland. ${ }^{14}$ German music, as well as the spoken and written word, helped to carry the words of German theological writings far and wide, as noted by Margrét Eggertsdóttir. ${ }^{15}$ According to Friederike Koch, some Icelanders dwelling in Hamburg learned Low German very quickly ${ }^{16}$ the guests did not only come into contact with the ideology of the Reformation and humanism, they also took over the continental way of life and brought it back to their country afterwards. The mixing of direct and mediate contacts resulted from such experiences.

\section{Cultural colonialism}

I would like to make use of the notion of 'cultural colonialism' and differentiate it from 'cultural imperialism', which - according to Kristina Wollf - is 'the practice of promoting one culture over another by forcing the own cultural beliefs and practices onto the conquered nation' in order to explain the quite influential status of Low German with respect to the Scandinavian languages, and to a lesser degree Icelandic as well. ${ }^{17}$

Since the Hanse was not a colonial power in a proper sense, it might seem inappropriate to speak of 'colonialism' or even 'imperialism'. Nevertheless, this economic network played such a prominent role in the North Atlantic that its influence exceeded the boundaries of the pure economic sector. Hanseatic traders also consistently influenced the entire culture of the people whom they came in contact with, from their way of living, to the building towns, and how they dressed. We should not forget that even if the Hanse originally pursued primarily economic targets, its political power increased enormously during the wars against the kingdom of Denmark (ending with the Treaty of Stralsund in May 1370). Considering the Italian Maritime Republics, Michael Mitterauer traced a close connection between their commercial interests and the military and political activities in the Mediterranean Sea and calls this phenomenon 'protocolonialism.' ${ }^{18}$ In my opinion, a very similar model can also be applied to the Hanse and their contacts in the Atlantic region.

'Cultural colonialism' has been studied as a byproduct of political colonialism, never as a topic within itself. This term, as sociology considers it, refers to two related practices: firstly, the extension of colonial power through cultural activities and institutions; and secondly, the asymmetrical influence of one culture over another. The latter is most often understood as the cultural domination of economically strong societies in the context of global capitalism, but applied to the Middle Ages, it may also refer to unequal societies being in contact with one another, whereby one society was culturally and economically predominant - even if not a colonial power - and the other rather a marginalized culture. ${ }^{19}$ Unlike sociologists, I am not willing to use the term synonymously with 'cultural imperialism' because this would also imply a more intentional plan of influencing the forms of cultural domination, including educational, academic, intellectual, scientific and linguistic colonialism. This was, of course, no explicit goal of the Hanse and did not occur in a systematic way.

The language in Iceland, however, was not greatly influenced due to several reasons, yet nevertheless, a sort of 'cultural colonization' by the Germans occurred through the Reformation. Starting from about 1470 German merchants began to visit Iceland. German trade with Iceland was mainly run from Hamburg against the policy of the Hanse. In the 1530s, perhaps even earlier, traders from Hamburg established their main base in Hafnafjörður, in the southwest of Iceland, not far from Reykjavík, where they built permanent timber houses. Thus, it was not through clerics, but German merchants, that the ideas of the new faith reached Iceland. Their 'conquest' was marked by the building of a church no later than 1537, where Lutheran services were performed, most likely first in German. ${ }^{20}$ A church tower can symbolically substitute a national 
flag in the act of settlement, as for instance during the polar expeditions. ${ }^{21}$ In this way the merchants - like colonialists - assigned themselves a space on foreign ground, imposing their own language and beliefs on it. The Reformation seems to have been the product of a double 'conquest' or 'subjugation' from the outside, i.e. for the first part by German merchants, and afterwards by the Danes who treated Iceland as a proper colony and imposed the change of religion as a political decision in 1550.

The aim of imperialism and colonialism was to expand the economic and power base of a nation and to assert its superiority. This was achieved in part by subjugating the local populations. Imperialism was not achieved only by using force, but also supported by the sense of superiority that the colonizers emanated. Colonial enterprise was very much supported by the existence of a social system, which firmly legitimized the cultural and social superiority of the colonizers. ${ }^{22}$ This kind of social system created two categories of people: the colonizers who were firmly located at the top of the social hierarchy and who were consistently identified with positive or prestigious values, as well as held the power and enjoyed the highest standing within society; opposite to them, the colonized people occupied a subordinate position.

Therefore, in the context of colonialism, Bettina Migge and Isabelle Léglise underlined the importance of understanding the cultural and specifically linguistic practices and they deny an exclusive focus on economic exploitation. ${ }^{23}$ As a matter of fact, the colonial discourse has been employed to justify colonial economic activities; yet discursive aspects about the superiority of the colonizers and the inferiority of the colonized people are never 'mere reflexes of the material domain'. ${ }^{24}$ According to Pennycook, the material exploitation of the colonies or their commercial activities was generally combined with the scientific, religious and cultural activities of the colonizers. The combination of all these aspects are essentially a manifestation of these discourses. In this regard, Foucault proposes a model of power and knowledge where these two aspects have a close connection, affirming that ' $[t]$ he longer I continue, the more it seems to me that the formation of discourses and the genealogy of knowledge need to be analysed, not in terms of types of consciousness, modes of perception and forms of ideology, but in terms of tactics and strategies of power ${ }^{25}$ (my emphasis).

Language played a central role in such a process: in terms of linguistic colonialism, scholars differentiate between two steps. The first one, called the 'vertical step', refers to the social spread of the language: the colonizers' language was first adopted by the upper class of the colonized people and only afterwards did it spread among members of the lower classes as well (as it happened in Scandinavia). ${ }^{26}$ The second one, called the 'horizontal step', involves the geographic perspective: the colonial language is diffused from the centre to the periphery. ${ }^{27}$ First, colonization gave rise to a (new) language hierarchy in which the language of the colonizer was deemed the most prestigious and came to dominate the administrative and mercantile structure of the colony ${ }^{28}$ It happened that the colonizers were generally described as possessors of culture, history, intelligence and know-how while the colonized were seen as lacking in all these vital characteristics. ${ }^{29}$ As a result, the language of the colonized populations generally borrowed a significant amount of lexical material from the colonial language. ${ }^{30}$ Auður Hauksdóttir observed correctly that loanwords were also used where a genuine Icelandic word existed. ${ }^{31}$ In this case, use was not dictated by need, but it denoted rather an ideological affiliation to the upper class, that is to say, linguistic influence was used in an elite-discourse.

Considering all of this, we can affirm that even if the German 'conquest' of Scandinavia and Iceland cannot be considered as a real colonial take-over - because it also lacked the coercive aspect - the criteria for 'linguistic and cultural colonialism' were still clearly present. The difference consisted of the fact that the German people did not need to overpower the other cultures and to impose their culture and language by making use of violence; rather, prestige emanating from their language and culture itself, made the upper class willing to take it over. Yet, I am fully aware of the fact that the Hanse did not act like a proper 'colonial power'; for instance, they did not try actively to influence the education system. Nevertheless, they affected the process of acculturation of their own culture and language on other cultures to a certain degree. On the one hand, this led to a drastic change of the Scandinavian languages and on the other hand to the introduction of Lutheranism.

\section{The influence of (Middle) Low German on the Scandinavian languages}

\section{Continental Scandinavian}

We shall now leave Iceland for a while and focus on Scandinavia, that is Denmark, Norway and Sweden. Much has already been written about the relationship between the German and Scandinavian languages and 
I am not going to refer to every aspect here in detail, but will outline the main tendencies. Low German, and in particular Middle Low German, has been very influential for all continental Scandinavian languages, which underwent drastic changes after the Middle Ages on a morphological as well as on a lexical level. ${ }^{32}$

As far as morphology is concerned, a gradual simplification in declension and inflection occurred. This lead to a radical modification of the original language which we could call an Old Norse koiné -; this describes the development from a highly inflectional idiom to different weakly inflectional languages. ${ }^{33}$ On the lexical level, many genuine Old Norse lexemes, which had been coined as loan translations, such as málfrae $i$ 'grammar' or samhljó đ'consonant', were substituted by Latin and Greek roots (through the mediation of Low and High German or directly through the use of Latin as the language of the learned). The consequences of this process were on the one hand a progressive and eventually irretrievable divergence from Icelandic and on the other hand the convergence to the other continental Germanic languages - German, English and Dutch.

Now the question arises as to how this could happen. Firstly, it was a pragmatic decision, due to the need for a medium of communication within the Hanseatic world for a period of about 300 years. Yet, Willy Diercks and Kurt Braunmüller have convincingly shown that the extra-linguistic dimension played the decisive role in this process. ${ }^{34}$ Scandinavians could have adopted other strategies, for instance, using Low German as lingua franca, or they could have established the conditions for a bilingual situation. Instead, they preferred to integrate a good part of Low German vocabulary into their own languages and to simplify their morphology.

Two factors should be considered in this regard: on the one hand the fairly late development of literacy in the North - mostly in Sweden and Denmark. ${ }^{35}$ In the time when Low German played an important part in the life of all Scandinavians, no norm or standard existed for the written language. This is probably the reason - on a socio-linguistic level - why the influence of the more advanced foreign culture could be strong enough to dictate the rules. On the other hand, the high social and cultural position of the Germans, due to their economic and political influence, made this development possible: Low German was given the status of a prestige language, thus the Scandinavian upper class was willing to integrate it into its own language use. ${ }^{36}$ Not only the traders, but also the nobility from Holstein was very influential and succeeded in imposing the use of Low German on the Swedish court of the fifteenth century.

\section{Icelandic}

Despite the linguistic stability of the Icelandic language by means of regulating the written norm through the quite early translation of the Bible, extra-linguistic factors led to the influence of other languages in the early modern period in Iceland. These languages are Middle Low German (High German to a certain extent) and Danish. Even if they were originally genetically close related languages, Danish had already undergone drastic changes in the Early Modern period that made it diverge from Icelandic to a great extent. The literary production in Iceland from this time has been disregarded for the most part due to its humble quality; a detailed investigation, however, reveals the strong influence of German and Danish on a language that became a mixed one. ${ }^{37}$

At the end of the nineteenth century, extra-linguistic - political as well as ideological - factors made the language undergo a new radical reform that cannot be discussed in detail in the present contribution. Political reasons played a prominent role in Iceland in the struggle for and against the 'purism' of the language, beginning in the post-Reformation era. ${ }^{38} \mathrm{In}$ fact, the efforts eliminating foreign influences from the language began very early on. In the early modern period, some learned people such as Arngrímur lærði Jónsson (1568-1648), argued in favour of a more pure Icelandic and against the political and cultural influence of foreigners. In his work Crymogcea (a history of Iceland in three volumes 1609), which is essentially a description of the geography and culture of his land written for a foreign audience, Arngrímur takes up arms in the name of the Icelandic language, affirming 'Yet I wish that my fellow countrymen would also include a third thing: namely, that instead of aping the language and writings of the Danes and Germans they would take the richness and the beauty of our mother tongue as an example and they would complete it with wisdom and sapience. Only in this way we can preserve the language from changing drastically, otherwise we will not even need contact with foreigners in order to corrupt the language. ${ }^{39}$

At the same time, or slightly later, the class of public officials, working against this policy, established a particular style, so-called kansellistill, which consisted of fifty percent of Danish lexemes. In many cases, these words do not represent pure Danish forms; rather they are Low German words that had been assimilated 
into Danish and continental Scandinavian in a prior time. This may be seen as an indirect influence of Low German on Icelandic through the mediation of Danish. The use of kansellistill increased to a greater degree after 1662, when the Althingi, the Icelandic parliament, lost its authority in favour of the Danish administrative apparatus. From that point onwards, the official language of legislation in Iceland was Danish. ${ }^{40}$

As different text genres were imported from the Continent, in particular from Denmark and Germany, it goes without saying that this also resulted in a strong influence on the Icelandic language. Yet the influence of the language contacts on Icelandic was in general less 'invasive' in comparison to other Scandinavian languages. At different stages of Icelandic history, the development of new words became necessary, starting with Christianization, then with technical progress, as well as political and social development (chancellery, Reformation etc.). Unlike in the other Scandinavian languages, this process did not have a very strong impact and did not modify the morphology of the language, operating only on the lexical level. Apart from the phonological system, which went through a reorganization of the quantity relations, morphology and syntax are still nearly the same as in Old Norse. ${ }^{41}$ As far as syntax is concerned, some examples of the foreign inflection and influence are recorded in the Lutheran Bible, from which phrases such as Germ. ich bin gewesen ('I have been') were literally translated as ég em verinn instead of the correct ég hef verið, or the use of the verb at the end of a subordinate clause (Gиð... in hvörs nafni vér skirðir erum 'God ... in whose name we all are baptized'). New words, some of which still exist (but most of them were removed after 1900) were adapted into the declension patterns of Icelandic, so that they soon lost the status of 'foreign words' and became assimilated 'loanwords'.

Thus, a fruitful area of linguistic contact was, from the beginning of Christianization onwards, in the religious sphere. First, contacts were established in the Middle Ages and were the result of direct relationships: the missionary Pangbrandr, sent by King Óláfr Tryggvason, likely came from Saxony. Later, King Óláfr the Saint sent further missionaries from England and Germany. Additionally, Icelandic clerics travelled to Germany in order to be educated in German universities.

All these different factors left more or less deep and durable signs on the cultural life of Iceland and on its language. Yet the degree of influence was different depending on the level of education of the speakers. Unlike the situation in Germany, Europe and Scandinavia, a considerable part of the Icelandic population could read and write, even without having attended one of the two official cathedral schools. In the case of Europe - in particular, Germany and Scandinavia - Rolf Engelsing spoke of a very low degree of literacy during the entire Middle Ages, independent of social classes, including priests, rulers, knights and the upper class in general. ${ }^{42}$

For a long period, between the sixteenth and the nineteenth centuries, different social classes participated in literacy in Iceland, even if a great variation existed in their competences. The learned who had attended an official school tried to obey the rules of Latin rhetoric and used them for vernacular poetry as well, as demonstrated recently by Margrét Eggertsdóttir. ${ }^{43}$ We can perceive a more conservative Icelandic and an avoidance of loanwords in the psalms composed by Hallgrímur Pétursson (1614-74). In his poetry, he was surely inspired by the vocabulary of the Guðbrandsbiblia. Jakob Benediktsson counted 200 borrowings in his psalms, but less than 100 are from the Reformation era, the others having been already integrated into the Icelandic language. ${ }^{44} \mathrm{~A}$ special group among them consisted in the priests and young theologians educated in Wittenberg or Jena who took German books back to their homeland - poems, sermon collections, and other edifying texts, together with a variety of literary works. Of course, they would have been influenced by their personal experiences in Germany and the literature they possessed. However, the influence of Low German was already evident before the Reformation due to printed media that had already begun to be imported by the end of the fifteenth century, for instance a considerable collection of vitae ('acts of saints').

In order to study the influence of Low German on Icelandic, specific genres seem to be more fruitful than others. Veturliði Óskarsson, for instance, has investigated Icelandic documents, i.e. certificates, charters and official letters, from 1200 until 1500. ${ }^{45}$

More than one thousand diplomata are preserved as originals, but many more are recorded in later transcriptions. Most of them concern the world of trade. Several loanwords attest to language transfer, presenting an older linguistic layer, such as prestr 'priest' and biskup 'bishop', together with a younger layer, like bréf 'letter' and stykki 'piece, part'. Even if the author has to admit that the influence of Low German was basically a secondary phenomenon, mostly due to the mediation of Norwegian and Danish, ${ }^{46}$ he must still recognize that several 'Hanseord' ('Hanseatic words'), i.e. words 
of Middle Low German origin, belonging for the most part to the language of trade and administration as well as fashion-words and other prestigious words, have been recorded too early to have been mediated through Danish. ${ }^{47}$ A group of words that were quite surely borrowed in the Hanseatic period are words with the prefix $b e-(=b i / b i$ in Icelandic). The oldest example is recorded in an episcopal statute from 1370 in the form of the verb bifala 'to command' (1370, < MLG bevalen); other verbs such as bihalda 'to retain' (1398, < MLG behölden) and birykta 'to enrich' (MLG beriken) follow from the end of the fourteenth century (further similar word constructions appear starting in the fifteenth century). ${ }^{48}$ Yet, not all the loanwords were borrowed directly from Low German; some of them reached Iceland through the mediation of Norwegian or Danish, as for instance the verb forbrióta 'to commit a crime' (< Norw./Dan. forbryte, previously taken from MLG vörbrēken $)^{49}$

A letter from 1406 states that three German carpets (priw aakladi pýversk) were delivered to Iceland. ${ }^{50}$ This means that at such an early time, trade, and thus contact of some form, already took place between Germany and Iceland.

Apart from the very small circle of learned people and the clergy who stood in dialogue with the European learned elite, we find a large group of laymen capable of reading and writing in Iceland more than anywhere else in Europe. All these groups were very productive and used different kinds of Icelandic: the first wrote both in Latin and Icelandic, just like the humanists, or in a relatively genuine Icelandic. In the context of the present contribution, the laymen are much more interesting. Their literary remains represent a wide corpus of unpublished manuscripts preserved primarily in the National Library of Iceland (Landsbókasafn Íslands) and which have been largely disregarded until now. The corpus consists of several disparate text genres among other prognostic texts, weather forecasts, herbal and medical books, collections of riddles, dream interpretations, edifying histories etc. ${ }^{51}$ Hans Joachim Kreutzer wrote an entire book trying to define the nature of this so-called 'Volksbuch', but preferred to restrict the text genre to a sort of novel (edifying histories). ${ }^{52}$ Unlike Jakob Benediktsson, ${ }^{53}$ who does not attribute a very high value to this kind of literacy for the study of post-Reformation culture and language, I am convinced that these texts provide us with a lot of valuable information. This literature shows pretensions of being scientific and learned - although it was not - by using numbers, tables as well as many for the most part incorrect references: for example, the name of Rudolph Goclenius (1547-1628), a German professor for philosophy who wrote two treatises on chiromancy and physiognomy, was consistently recorded as Rudolph Galenus. In my opinion, it is in this context that we should consider the excessive use of loanwords in this kind of literature, namely in the effort to appear up-to-date and more learned than one may have been. However, the fact that the loanwords are often accompanied by a genuine Icelandic lexeme (such as the tautological expression litur og farve, meaning simply 'colour') shows uncertainty in the handling of the foreign words.

Another kind of linguistic expression, of which we can know only little, is the spoken language. It is impossible to determine whether people used the same kind of words in their spoken language as well or if they spoke a more genuine Icelandic. In this regard, Jakob Benediktsson is against the hypothesis of the use of the same kind of language in the spoken variant. ${ }^{55} \mathrm{He}$ argued that Icelandic society still maintained a medieval social structure and that therefore people continued to speak the language they had spoken for centuries. I certainly agree about the conservative nature of Icelandic society, but I am not sure that Jakob Benediktsson presents convincing arguments - at least from a linguistic point of view.

\section{Stabilizing factors of the Icelandic language}

Despite all this 'colonization', some important factors prevented the development of the Icelandic language parallel to Norwegian, which also constituted a part of Old West Norse. On the one hand, linguistic stability was surely favoured by the country's geographical and cultural isolation in the early modern period, in which the possibilities of direct contacts became more seldom.

Before this period, from $c .1470$, German merchants began frequently to visit Iceland. Despite the fact that the Germans dominated the greater part of trade with the island in 1540 - or maybe because of it - King Christian III (who ruled 1534-59) started a new Iceland policy and in 1542 he imposed the prohibition of winter dwelling for foreigners on the island. After 1602, his successor King Christian IV (1596-1648), prohibited traders from Hamburg from coming to Iceland at all..$^{56}$

Yet another factor that supported linguistic stability in the Icelandic language seems to have been widespread literacy, dating back to the Middle Ages, which 
provided a fixed norm for the language. ${ }^{57}$ As a matter of fact, the Icelandic version of the New Testament by Oddur Gottskálksson (1536/37) is the thirteenth translation of a longer biblical text written in the vernacular in the world. ${ }^{58}$ The conservative language of the biblical translation, in particular the Guðbrandsbiblia (1584), represented a normative and stabilizing factor until the eighteenth century. On the other side of the Atlantic Ocean in Norway, the clergy did not succeed in translating the Bible, psalms and catechism into Norwegian, but adopted the Danish version of these texts instead. ${ }^{59}$ As a consequence, they lost their own language in favour of Danish. By contrast, Icelandic became the language of the church, as well as of scholarship; it was preserved within the society as the main language and was used in every learned and unlearned field of life. The largest contingent of German influences on the language occurred in a period when the Icelandic language was already established and standardized to a certain degree through the translations of the biblical texts. This is probably the reason why linguistic contact operated only on the lexical level and did not drastically influence morphology and syntax. Due to all these factors, the Low German 'expansion' could not achieve the strong impact on Icelandic that it had had on the other Scandinavian languages and did not have an enduring influence on it. ${ }^{60}$

\section{Conclusion}

The above-mentioned examples were meant to illustrate how languages, due to extra-linguistic factors, interact with each other and are influenced from the outside. Even if the examples are not numerous, they are perhaps sufficient in showing that even a very conservative language like Icelandic was influenced by the German language at a certain moment in history and in a later period by Danish as well. The reasons are partly to be found in the insufficiency of the language to express new concepts, such as technological achievements or new cultural trends and movements; first and foremost, however, it was extra-linguistic factors that played the most relevant role. Among these factors was the effort given to adopting the language of the upper class or a more advanced culture so as not to risk the imposition of standing out from other cultures. Using the words of Willy Diercks and Kurt Braunmüller we can agree that 'Middle Low German was considered a carrier of culture and innovation as well as a mediator between southern Europe, which was well-developed in many fields, and the hesitantly developing North. For this reason, the argument of the prestige and the additional social value of the southern language is applied in order to understand the quick and widespread advance of Low German. ${ }^{61}$

The present contribution has tried to demonstrate that the investigation of languages should cross the borders of linguistics and incorporate the study of a wide field of socio-political discourses.

\section{Appendix}

The following lists show by means of a few examples, which parts or aspects of the German language were adopted by the Scandinavian languages as well Icelandic at different times. Furthermore the third section presents different strategies of the adaptation of foreign linguistic stock into Icelandic, as they were recorded in the early modern period when this idiom was strongly influenced by German (and Danish). ${ }^{62}$

\section{Examples of language transfer}

Older linguistic layer coming partly from Old English influence:

ON prestr 'priest' < OE prēost

ON biskup 'bishop' < OE bisceop

Younger linguistic layer coming mostly from Middle Low German:

ON alltið 'always' < MLG alletitt

ON arligr 'honest, honourable' < MLG èrlik

ON blifa 'become' < MLG bliven

ON bréf'letter'< MLG brev

ON leikr adj. 'unlearned' < MLG lck (< lat. laicus)

ON náð 'help/grace' < Old Saxon (ge)nätha

ON stykki 'piece, part' < Germ. Stück

ON reisa 'travel' < MLG reise, rēse

\section{Examples of borrowings from MLG in the Icelandic diplomata}

OIc. borga 'pay/guarantee' < MLG börgen

OIc. formera 'to shape' < MLG form

OIc. hertuginna 'duchess'< MLG hertugin

OIc. hústrú 'housewife'< MLG hūstrū

OIc. hoeve(r)skr / hoeverskligr 'courtly, fine' < MLG

hovelik

OIc. krankr 'ill/sick' < MLG krank

OIc. máltì 'meal' < MLG māltit

OIc. máta 'to try on' < MLG mäten

OIc. orlof 'permission' < MLG orlof

OIc. partr 'part'< MLG part

OIc. próf 'testimony' < MLG prôve 
OIc. reikna 'to calculate' < MLG rēcken

OIc. skyldugr 'indebted' < MLG subst. schult

OIc. ara 'honour'< MLG ère

\section{Strategies of adaptation into Icelandic}

Adoption of foreign words in Icelandic

Nouns:

gunst 'favour, patronage' (< Germ. Gunst)

- angist 'fear, anxiety' (<MLG angest, also assimilated in Danish angst)

- the phrase hafa makt 'to have power/influence on something', where makt is a loanword from MLG macht

\section{Adjectives:}

- dicktande 'versifying' < Germ. dichtend

Verbs:

- purgera 'to purge' < MLG purgieren

- regera 'to rule' < Germ. regieren

- behaga 'to suit, to please' < MLG behagen

Use of a genuine Icelandic word associated with a loanword in tautological phrases:

- farfi og litur, meaning just 'colour' (Germ. Farbe 'colour' which influenced also Dan. farve, Norw. farge vs. Old Norse litr 'colour')

- grafa málm og metal(l) 'to excavate metal', with metall instead of Mod.Ic. málmur (< Germ. < Latin and Greek)

Creation of neologisms combining Icelandic roots and German affixes

Suffix is -heit for the creation of nouns:

- sniðug-heit 'cleverness', deriving from Ic. sniðugur

'clever' + Germ. suffix - heit

- kerleg-heit 'reputation', composed by the Icelandic adjective kerlegur 'esteemed' + Germ. suffix - heit

- herleg-heit 'splendour, superbness' as a complex word building consisting in the adjective MLG hêrlik + Germ. suffix -heit to create the abstract concept

Prefix be- derived from German starting from the fifteenth century

- Some borrowings were directly assimilated only by adapting the phonology:

Dan. bekrcefte 'to confirm' < MLG bekreften

Dan. bekoste 'to pay' < MLG bekosten

Dan. berede 'to prepare' < MLG berêden

Dan. begynde 'to begin' < MLG beginnen
- Others were translated:

Dan. bevidne 'to witness' = Germ. bezeugen

Dan. begribe 'to comprehend' = MLG begripen

Prefix for-: the unstressed for-< MLG vor-/ver-, the stressed one $<$ vore-/vor-

- for-geingulegur 'transitory, ephemeral' < Germ. vergänglich

- for-standigur 'sensible, discreet' < Germ. verständig

\section{Endnotes}

${ }^{1}$ Dalby 2004, 182.

${ }^{2}$ Cf. Hinderling 1981, 10. Linguistic contacts took place over approximately 700 years; the first period of influence concerned Middle Low German (thirteenth to sixteenth centuries) and from the sixteenth century onwards High German. Regardless of the political situation, the Germans maintained economic, religious and cultural power until the second part of the nineteenth century. Indeed, they had a prestigious status, whereas the majority of the Estonian people were peasants (cf. ibid., 94). Influence occurred on every linguistic level; that is on a lexical level as well as a morphological and syntactical level. At a certain time period, a hybrid language consisting of a mixture of German and Estonian was also widespread. This hybrid language had been developed by the local people working for the foreign upper class.

${ }^{3}$ In this regard, Todorov $(1999,219)$ fittingly illustrated the language policy of the Conquistadores in South-America. The colonized people had to learn the language of the new upper class and to adopt its religion, but only to a certain extent. 'Language has always been the companion of empire; the Spaniards' fear in losing supremacy over the former realm, they may lose it over the latter as well', that is to say, if the indigenous people had learned the language so well that they could speak it freely, the colonizers would have lost an important instrument of oppression. On the other hand, they did not bother to learn the language of those they subjugated. That is why Todorov $(1999,219)$ correctly observed 'usually it is the conquered who learns the conqueror's language. It is no accident that the first interpreters were Indians'.

${ }^{4}$ Braunmüller 1995.

${ }^{5}$ Ibid., 14: 'die Verständigung mittels der eigenen (Mutter-) Sprache beim Kontakt mit genetisch eng verwandten Sprachen'.

${ }^{6}$ Diercks and Braunmüller 1993.

${ }^{7}$ Braunmüller and Kühl 2014, 16.

${ }^{8}$ Diercks and Branmüller 1993, 10.

${ }^{9}$ Marold 1980.

${ }^{10}$ Branmüller and House 2009, 1.

${ }^{11}$ Westergård-Nielsen 1946, xxxvi.

${ }^{12}$ Ibid., xxxv.

${ }^{13}$ In this particular case Marold $(1996,43)$ brings attention to the several loan translations developed 'vor dem Schreibpult' ('on the slant-top desk').

${ }^{14}$ Koch 1995, 363.

${ }^{15}$ Eggertsdóttir 2014, 19. 
${ }^{16}$ Koch 1995, 50.

${ }^{17}$ Wollf 2009, 906.

${ }^{18}$ Mitterauer 2005.

${ }^{19} \mathrm{Cf}$. Amsler 2016. On the different forms of colonialism see also Osterhammel and Jansen 2017.

${ }^{20}$ Karlsson 2000, 123ff.

${ }^{21}$ Eglinger and Heitmann 2010, 20.

${ }^{22}$ Cf. Pennycook 1998.

${ }^{23}$ Migge and Léglise 2007.

${ }^{24}$ Ibid., 38.

${ }^{25}$ Cited from Childs and Williams 1997, $98 \mathrm{f}$

${ }^{26}$ In this regard, Bloomfield $(1996,461)$ spoke of 'intimate borrowings' to be found 'when two languages are spoken in what is topographically and politically a single community', and he explains it as a process occurring when ' $[t]$ he upper language is spoken by the dominant and privileged group; many kinds of pressure drive the speaker of the lower language to use the upper language'. See also Marold 1996.

${ }^{27}$ Migge and Léglise 2007, 5. In regard to the 'vertical step', Wessén $(1968,113)$ wrote about the situation in Sweden: 'Im Mittelalter wurde eine große Zahl niederdeutscher Lehnwörter übernommen, vor allem solche, die den Handel, das Handwerk, das Städtewesen und das Ritterleben betrafen, aber auch eine Menge anderer alltäglicher Wörter. [...] Zweifellos haben diese deutschen Bezeichnungen, die in mehreren Fällen ältere, einheimische Wörter und Ausdrücke ersetzt haben, anfänglich der vornehmeren und moderneren Sprache der Adligen und Stadtbürger angehört und sind allmählich in die Sprache der Bauern auf dem Lande eingedrungen'.

${ }^{28}$ Migge and Léglise 2007, 6.

${ }^{29} \mathrm{Cf}$. Pennycook 1998, 47ff.

${ }^{30}$ Migge and Léglise 2007, 9.

${ }^{31}$ Hauksdóttir 2011, 9f.

${ }^{32}$ On the contact between Middle Low German and the Scandinavian langauges see Johannisson 1968, Hyldgaard-Jensen 1983 and Jahr 1995.

${ }^{33}$ Cf. Wessén 1968; see also Groenke 1998, 46f. and 60ff. Groenke $(1998,60)$ defined the degree of linguistic detachment also within Old West Norse as enormous, i.e. Old Icelandic and Old Norwegian, two languages with a very close genetic relationship. The linguistic split occurred in the fourteenth/fifteenth centuries, after which their speakers did not understand each other any longer (ibid., 87: 'unüberbrückbare Trennung'). Marold $(1996,44)$ saw in this process a 'natural' development of the languages and not, as believed in the past, the influence of Middle Low German on the inflexion system.

${ }^{34}$ Diercks and Braunmüller 1993.

${ }^{35}$ In regard to Danish literary production of the fourteenth and fifteenth centuries, Wessén $(1968,82)$ affirmed that it consisted mostly of translations from the religious sphere.

${ }^{36}$ Braunmüller 1993, 142.

${ }^{37}$ I have touched on this topic in the context of the analysis of Icelandic astrological-astronomical sources ( $c f$. Bauer 2015, 38-42).

${ }^{38}$ Cf. Ottósson 1990.

${ }^{39}$ My translation. $C f$. p. 29 of the edition. The original reads '[v]ellem his tertium à modernis nostratibus adjungi: $\mathrm{Ne}$ scilicet scribentes aut loquentes vernaculè Danizarent aut Geramnizarent, sed ad linguæ patriæ, per se satis copiosæ et elegantis, copiam et elegantiam anniterentur, eamque sapienter et doctè affectarent; minus profectò in posterum mutationis periculum metuendum foret. Alioqui ad corrumpendam linguam non opus erit exterorum commerciis.' Liber primus, caput III.

${ }^{40}$ Benediksson 1964, 106.

${ }^{41}$ Kress 1966.

${ }^{42}$ Engelsing 1973.

${ }^{43}$ Eggertsdóttir 2014.

${ }^{44}$ Benediktsson 1964, 101.

${ }^{45}$ Óskarsson 2003.

${ }^{46}$ Ibid., 15.

${ }^{47}$ Ibid., 29: 'På trods af alt dette er mange 'hanseord', d.v.s. ord af middelnedertysk oprindelse som først og fremmest tilhører handels- og administrationssproget, modeord og andre ord som har en klar prestigeklang, så tideligt på færde at de ikke kann være kommet ind gennem dansk.'

${ }^{48}$ Ibid., 29 f.

${ }^{49}$ This record is found in a law reform for trade and duty, issued in Bergen in 1383, see Óskarsson 2003, 54.

${ }^{50}$ Ibid., 49. See also DI III, no. 587.

${ }^{51}$ Niepage 1993, 55.

${ }^{52}$ Kreutzer 1977; see also Müller 1985. For this comprehensive kind of popular literature, I have chosen the term 'Haushaltsbücher', which should be understood as 'popular literature for every household' ( $c f$. Bauer 2015).

${ }^{53}$ Benediktsson 1964, 102.

${ }^{54}$ Hauksdóttir 2011, 9 f.

${ }^{55}$ Benediktsson 1964, 102.

${ }^{56}$ Westergård-Nielsen 1946, xxxvii.

${ }^{57}$ Braunmüller and Kühl 2014, 22.

${ }^{58}$ Wahl 2008, 50.

${ }^{59}$ Koch 1995, 50.

${ }^{60}$ Westergård-Nielsen 1946, xxxix.

${ }^{61}$ Diercks and Braunmüller 1993, 10 (my translation): '[d]ie mittelniederdeutsche Sprache gilt als Trägerin kultureller und wirtschaftlicher Innovation wie auch als Vermittlerin zwischen dem auf vielen Gebieten fortschrittlicheren Süden und dem sich später entwickelnden Norden. Dementsprechend wird auch das Argument des Prestiges, des gesellschaftlichen Mehrwerts der südlichen Sprache, zur Deutung des schnellen und umfassenden Vordringens des Niederdeutschen verwendet.'

${ }^{62}$ Part of the examples are taken from Falk and Torp 1910.

\section{References}

Printed sources (see also list of abbreviations)

Crymogae sive Rerum Islandicarum Libri III, by Arngrímur Jónsson. Hamburg, 1609.

\section{Secondary literature}

Amsler, S. 2016. Cultural colonialism, in The Blackwell Encyclopedia of Sociology. https://doi.org/10.1002/9781405165518.wbeosc202.pub2

Bauer, A. 2015. Laienastrologie im nachreformatorischen Island: Studien zu Gelehrsamkeit und Aberglauben. Münchner Nordistische Studien 21. München: Herbert Utz Verlag. 
Benediktsson, J. 1964. Pættir um sögu íslenzks orðaforða, in H. Halldórsson (ed.), Dattir um íslenzkt mál, 88-109. Reykjavík: Almenna bókafélagið.

Bloomfield, L. 1996. Language. Dehli: Allen \& Unwin.

Braunmüller, K. 1993. Übernahme von Sprachstrukturen, in K. Braunmüller and W. Diercks (eds), Niederdeutsch und die skandinavischen Sprachen 1, 137-160. Heidelberg: Winter Verlag.

Braunmüller, K. 1995. Formen des Sprachkontakts und der Mehrsprachigkeit zur Hansezeit, in K. Braunmüller (ed.), Niederdeutsch und die skandinavischen Sprachen 2, 9-33. Heidelberg: Winter Verlag.

Braunmüller, K. and House, J. 2009. Introduction, in K. Braunmüller and J. House (eds), Convergence and Divergence in Language Contact Situations, 1-9. Hamburg Studies on Multilingualism 8. Amsterdam and Philadelphia: Benjamins.

Braunmüller, K. and Kühl, K. 2014. Linguistic stability and divergence: An extended perspective on language contact, in K. Braunmüller, S. Höder and K. H. Kühl (eds), Stability and Divergence in Language Contact. Factors and Mechanisms, 13-38. Studies in Language Variation 16. Amsterdam and Philadelphia: Benjamins.

Childs, P. and Williams, P. 1997. An Introduction to PostColonial Theory. London: Prentice Hall.

Dalby, A. 2004. Dictionary of languages: the definitive reference to more than 400 languages. New York: Columbia University Press.

Diercks, W. and Braunmüller, K. 1993. Entwicklung des niederdeutsch-skandinavischen Sprachkontakts, in K. Braunmüller and W. Diercks (eds), Niederdeutsch und die skandinavischen Sprachen 1, 9-40. Heidelberg: Winter Verlag.

Eggertsdóttir, M. 2014. Icelandic Baroque. Poetic Art and Erudition in the Work of Hallgrimur Pétursson. Ithaca and New York: Cornell University Library.

Eglinger, H. and Heitmann, A. 2010. Landnahme: Anfangserzählungen in der skandinavischen Literatur um 1900. Paderborn and Munich: Fink.

Engelsing, R. 1973. Analphabetentum und Lektüre. Zur Sozialgeschichte des Lesens in Deutschland zwischen feudaler und industrieller Gesellschaft. Stuttgart: Mezler.

Falk, H. S. and Torp, A. 1910. Norwegisch-dänisches etymologisches Wörterbuch auf Grund der Übersetzung von Dr. H. Davidsen neu bearbeitete deutsche Ausgabe mit Literaturnachweisen strittiger Etymologien sowie deutschem und altnordischem Wörterverzeichnis. Heidelberg: Winter Verlag.

Groenke, U. 1998. Die Sprachenlandschaft Skandinaviens. Berlin: Weidler.

Hauksdóttir, A. 2011. Danske minder i Island. Om mødet mellom dansk og islansk kultur. Danske Studier 106 (NF 10), 5-49.

Hinderling, R. 1981. Die deutsch-estnischen Lehnwortbeziehungen im Rahmen der europäischen Lehnwortgeographie. Wiesbaden: Otto Harrassowitz.

Hyldgaard-Jensen, K. 1983. Mittelniederdeutsch und die skandinavischen Sprachen, in G. Cordes and D. Möhn (eds), Handbuch zur niederdeutschen Sprach- und Literaturwissenschaft, 666-76. Berlin: Erich Schmidt Verlag.
Jahr, E. H. 1995. Niederdeutsch, Norwegisch und Nordisch, in K. Braunmüller (ed.), Niederdeutsch und die skandinavischen Sprachen 2, 125-44. Heidelberg: Winter Verlag.

Johnannisson, T. 1968. Deutsch-nordischer Lehnwortaustausch, in W. Mitzka (ed.), Wortgeographie und Gesellschaft, Festgabe für Ludwig Erich Schmitt zum 60. Geburtstag am 10. Febr. 1968, 607-23. Berlin: Walter de Gruyter.

Karlsson, G. 2000. Iceland's 1100 Years. The History of a Marginal Society. London: Hurst \& Co.

Koch, F. C. 1995. Untersuchungen über den Aufenthalt von Isländern in Hamburg für den Zeitraum 1520-1662. Hamburg: Verein für Hamburgische Geschichte.

Kress, B. 1966. Anglo-Amerikanisch und Isländisch. Nordeuropa. Jahrbuch für Nordische Studien 1, 9-22.

Kreutzer, H. J. 1977. Der Mythos vom Volksbuch: Studien zur Wirkungsgeschichte des führen deutschen Romans seit der Romantik. Stuttgart: Metzler.

Marold, E. 1980. Mischsprache oder Kontinuum. Die skandinavisch-deutschen Sprachbeziehungen im Mittelalter im Licht der neueren Forschungen zum Sprachkontakt, in H. Rupp and H.-G. Roloff (eds), Akten des VI. Internationalen Germanisten-Kongresses in Basel 1980, 142-148. Frankfurt: Peter Lang.

Marold, E. 1996. Der Hansekaufmann als sprachlicher Grenzgänger, in H. Detering (ed.), Grenzgänge. Skandinavisch-deutsche Nachbarschaften, 28-45. Göttingen: Wallstein-Verlag.

Migge, B. and Léglise, I. 2007. Language and colonialism. Applied linguistics in the context of creole communities, in M. Hellinger and A. Pauwels (eds), Language and Communication: Diversity and Change. Handbook of Applied Linguistics, 297-338. Berlin: Mouton de Gruyter.

Mitterauer, M. 2005. Kaufleute an der Macht. Voraussetzungen des Protokolonialismus in den italienischen Seerepubliken am Beispiel Pisa, in P. Feldbauer, G. Liedl and J. Morrissey (eds), Mediterraner Kolonialismus. Expansion und Kulturaustausch im Mittelalter, 82-110. Essen: Magnus-Verlag.

Müller, J.-D. 1985. Volksbuch/Prosaroman im 15./16. Jahrhundert: Perspektiven der Forschung. Internationales Archiv für Sozialgeschichte der deutschen Literatur 1, 1-128.

Niepage, G. 1993. Rezeptionsbedingungen volkssprachlicher Erzählstoffe, in K. Braunmüller and W. Diercks (eds), Niederdeutsch und die skandinavischen Sprachen 1, 51-86. Heidelberg: Winter Verlag.

Óskarsson, V. 2003. Middelnedertyske låneord $i$ islandsk diplomsprog frem til år 1500. Copenhagen: Reitzel.

Osterhammel, J. and Jansen, J. C. 2017. Kolonialismus. Geschichte, Formen, Folgen. 7th edition. München: C.H. Beck Verlag.

Ottósson, K. G. 1990. Íslensk málhreinsun. Sögulegt yfirlit. Rit Íslenskrar málnefndar 6. Reykjavík: Letuprent.

Pennycook, A. 1998. English and the Discourses of Colonialism. London: Routledge.

Todorov, T. 1999. The Conquest of America: The Question of the Other. Norman: University of Oklahoma Press.

Wahl, B. 2008. Isländisch: Sprachplanung und 
Sprachpurismus. Skandinavistische Arbeiten 23. Heidelberg: Winter Verlag.

Wessén, E. 1968. Die nordischen Sprachen. Berlin: Walter de Gruyter \& Co.

Westergård-Nielsen, C. 1946. Låneordene i det 16. århundredes trykte islandske litteratur. Bibliotheca Arnamagnæana 6. Copenhagen: Munksgaard.

Wollf, K. 2009. Cultural imperialism, in G. Ritzer (ed.),

The Blackwell Encyclopedia of Sociology 2, 906-908. Malden: Blackwell. 